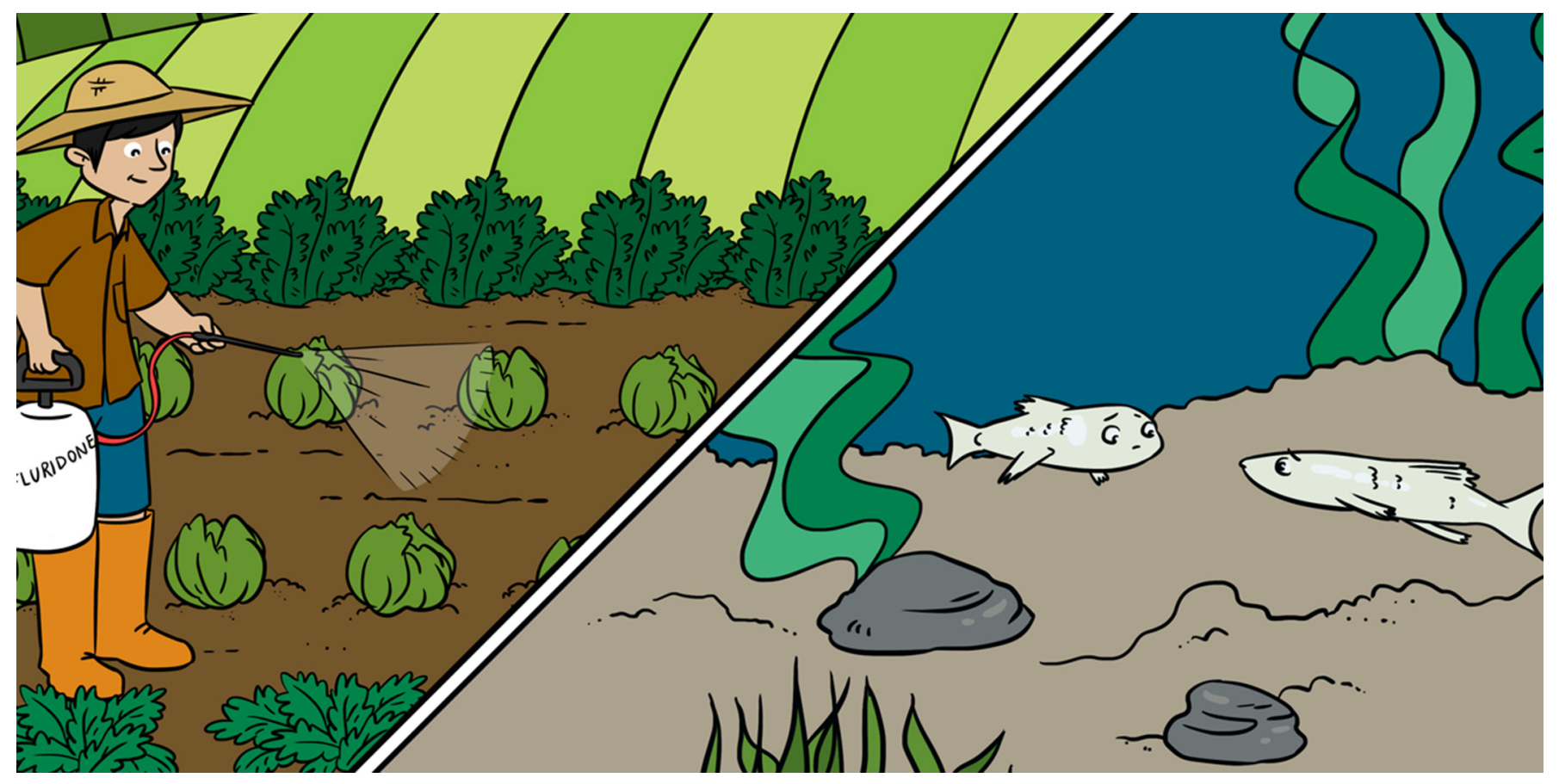

\title{
WHAT DOES NOT KILL CAN WEAKEN: HOW HERBICIDES IMPACT FISH IN THE SAN FRANCISCO
} ESTUARY

\section{Khiet Huynh ", Tomofumi Kurobe ${ }^{\dagger}$, Marie Stillway, Chelsea Lam and Swee Teh}

Aquatic Health Program, University of California, Davis, Davis, CA, United States

\section{YOUNG REVIEWERS:}

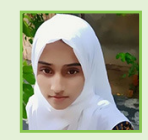

SAMEEN

AGE: 15

ZAINAB

AGE: 12
Farmers in the San Francisco Estuary have been using increasing amounts of weed killers, also called herbicides, on their farms. Herbicides kill unwanted weeds without hurting food crops. However, did you know that herbicides can hurt fish as well, especially those that live in the Estuary, like delta smelt? Delta smelt are small, translucent fish that only occur in the San Francisco Estuary. In the past, delta smelt could be found everywhere in the Estuary. However, they are currently threatened with extinction, largely due to human activities. In this study, we tested the toxicity of fluridone, a commonly used herbicide found in the San Francisco Estuary, on delta smelt. None of the fish died from fluridone, but we found that it weakened them, even after as little as $6 \mathrm{~h}$ of exposure! 


\section{HERBICIDE}

A substance that is toxic to plants, used to kill unwanted plants.

\section{ESTUARY}

A partially enclosed coastal body of brackish water with one or more rivers or streams flowing into it, and with a free connection to the ocean.

\section{FLURIDONE}

A chemicals used to get rid of aquatic plants.

\section{PELAGIC FISH}

A fish that stays in the upper and middle layers of a body of water, not close to the bottom or near the shore.

\section{WHAT ARE WEED KILLERS AND HOW DO THEY GET INTO THE SAN FRANCISCO ESTUARY?}

Weeds are always a problem for farmers and homeowners everywhere. They steal water from crops and prevent crops from growing well. Pulling weeds out of the soil by hand can be tiring and disappointing-some weeds come right back! In the early twentieth century, scientists began to develop chemicals called weed killers or herbicides, which kill weeds without hurting crops. Now, most farmers in the world use herbicides because they are very effective and easy to use.

The San Francisco Estuary is surrounded by a lot of farmland, and most farmers in the area spray herbicides onto their crops. Some of these herbicides remain in the soil. Then, rain or snow washes them into canals, streams, and rivers, and eventually into the Estuary. Some herbicides are even applied directly to the rivers in the Estuary. For example, in 2014, the San Francisco Estuary suffered a terrible drought. Low water levels and high temperatures allowed aquatic weeds to grow rapidly. Some of these plants were introduced by human activities, like the release of aquarium plants into the river. Their growth dominated other native plants, altered water flow, and blocked the movement of boats in the river. To resolve this problem, local agencies used several herbicides, including fluridone, to kill the aquatic weeds.

As researchers monitored water quality in the San Francisco Estuary, they detected low levels of these herbicides. Since herbicides are designed to kill only aquatic plants, low levels of fluridone were thought to be safe for aquatic animals. However, we were suspicious that low levels of fluridone might make fish sick, without killing them. Several research studies reported that low levels of herbicides prevented Atlantic salmon and rainbow trout from growing [1, 2]. We hypothesized that fluridone was causing similar negative effects on the growth of native fish species in the San Francisco Estuary.

\section{HOW DID WE TEST THE EFFECTS OF FLURIDONE ON FISH?}

To test our hypothesis, we used delta smelt as our test subject (Figure 1). The delta smelt is a small pelagic fish that smells like cucumbers and can only be found in the San Francisco Estuary. Since the Estuary is the only place that they live, any change in the Estuary can harm their entire population. In fact, the delta smelt is currently an endangered fish species that is nearing extinction, largely due to human activities. By testing the toxicity of herbicides on delta smelt, we hoped to find a way to protect their population. 
Figure 1

The delta smelt is a species of fish found only in the San Francisco Estuary (Image credit: UC Davis Fish Culture and Conservation Laboratory).

\section{BIOMARKER}

A measurable substance in an organism that indicates some internal change in the body, such as disease, infection, or environmental exposure to poisons.

\section{HORMONE}

A messenger substance produced by living organisms that stimulates cells or organs into action.

\section{ANTIOXIDANT}

A substance that prevent oxygen group to be added to other substances.

\section{ENZYME}

A substance produced by living organisms that helps a chemical reaction to happen more quickly in the body.



Figure 1

In medicine, general symptoms like a headache or stomachache are often not enough for doctors to diagnose a patient accurately. Doctors often need to further examine any chemical changes that are happening within the patient's body. Since we cannot look at these chemicals with our naked eyes, biomarkers are the tools we use to detect any internal chemical changes. A biomarker is a chemical or a substance in the body that we can measure to evaluate how sick the body is. When we are sick or in distress, our bodies fight against the illness or injury, which changes the levels of biomarkers in our bodies. By looking at these changes, we can accurately diagnose what is happening within the body. For example, doctors frequently look at chemical changes in the blood. If they detect a high level of insulin in the blood, they can predict that the person may have a disease called diabetes. In this way, insulin acts as a biomarker that predicts diabetes. For our study, we used biomarkers to determine whether fluridone caused any chemical changes in fish.

To prepare for the experiment, we used 20-liter buckets to hold the fish. They were filled with fresh water from the nearby river where delta smelt live, and we placed them in a water bath where the temperature was kept at $15.7^{\circ} \mathrm{C}$ with a water heater. Delta smelt grow well when the water temperature is around $16^{\circ} \mathrm{C}$, so we adjusted the bath to that temperature to keep them happy. We divided the buckets into two groups: experimental and control. For the buckets in the experimental group, we added fluridone to the water. The buckets in the control group only contained clean water, without fluridone. Then, we put in 10 adult fish into each bucket and attached a bubbler to each bucket so the fish would have air to breathe. After $6 \mathrm{~h}$, we collected the fish from both the experimental and control buckets and measured three biomarkers: a growth hormone, an antioxidant, and a brain enzyme. The growth hormone lets us know how well fish will grow and mature; the antioxidant indicates if the fishes' bodies are under stress or not; and the brain enzyme tells us if the fishes' brains are working properly. We compared measurements of the three biomarkers from both groups and looked for any differences between them (Figure 2). 


\section{Figure 2}

In our experiment, we tested whether a $6 \mathrm{~h}$ exposure to fluridone affected three biomarkers in delta smelt. All fish survived after the exposure. However, we found fish in experimental group have higher level of sex hormone and lower level of antioxidant and brain enzyme comparing to control group which told us that fluridone is making fish sick.

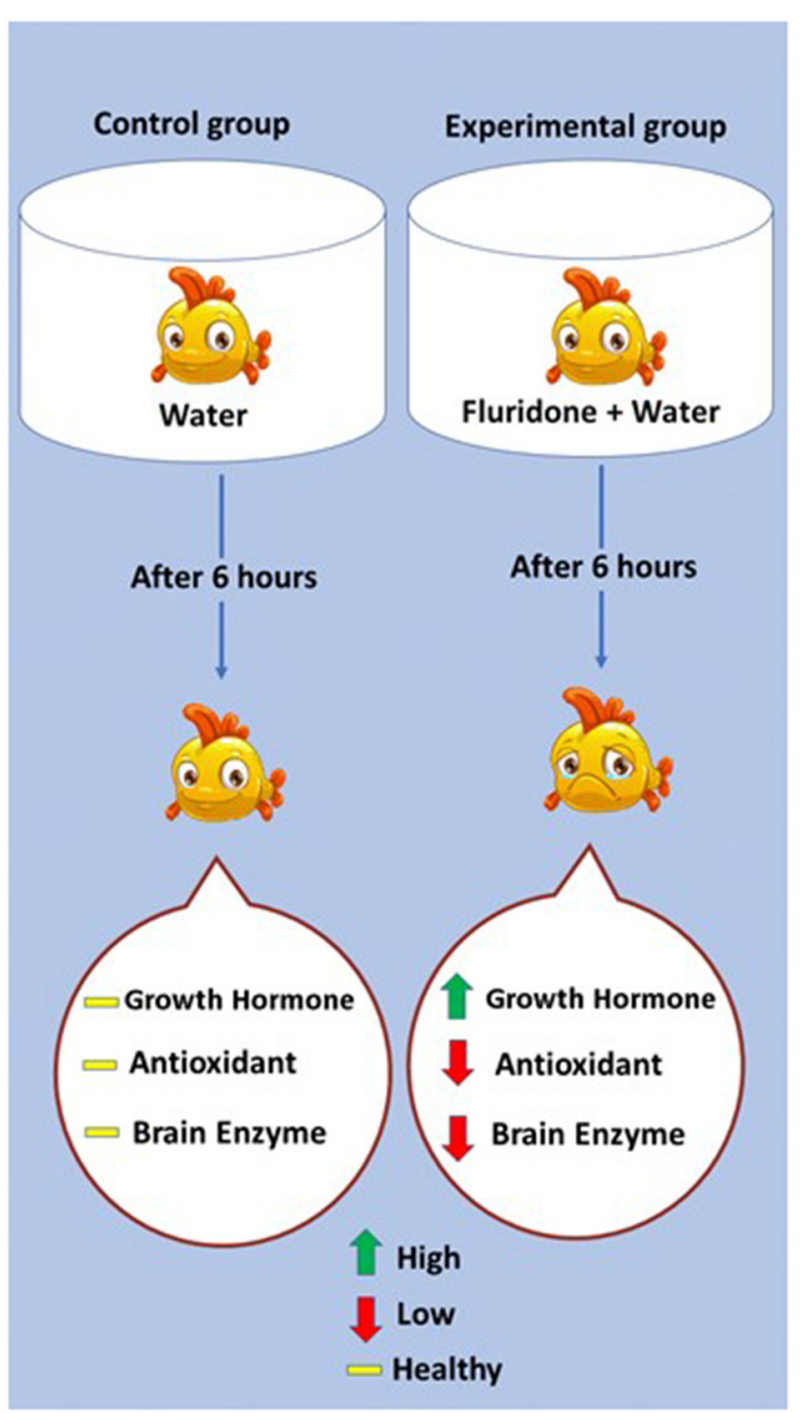

Figure 2

\section{IS FLURIDONE BAD FOR DELTA SMELT?}

All fish in the experimental group survived after $6 \mathrm{~h}$ of exposure to fluridone! This was good news. However, the levels of the three biomarkers told us that the fluridone made the fish sick, even though we could not see it.

We found that fluridone increased the level of growth hormone in delta smelt. Growth hormone controls the rate at which a fish matures. It causes female fish to start making eggs and triggers changes in behavior, skin color, and fin shape, all of which distinguish female fish from male fish. High levels of growth hormone can be bad for both female and male fish, preventing them from maturing correctly or reproducing properly. High levels of growth hormones cause female delta smelt to lay fewer, poor-quality eggs. Exposure to high level of growth hormone can be so strong that a male fish can change into a female fish! 
We also observed that fluridone lowered the level of brain enzymes in the brains of delta smelt. The brain controls many bodily mechanisms by making chemicals that signal other parts of the body. Brain enzymes control how strong these signals are. A decreased level of brain enzymes could slow the activities of delta smelt, such as finding food or swimming away from predators. Therefore, lower brain enzymes could mean lower survival in the Estuary.

Last, we found that fluridone lowered the level of antioxidant in fish. Bodies produce a lot of chemicals throughout the day, many of which are vital to the body's functions. However, too much of even good chemicals can put a lot of stress on the body. Antioxidants help get rid of the extra chemicals and maintain a healthy balance of chemicals in the body. Without antioxidants, chemicals begin to build up. Long exposure to fluridone might result in high levels of chemicals that could injure the internal organs of the fish (like the liver or kidneys), weaken the fish, and eventually cause them to die.

\section{WHAT DID WE CONCLUDE?}

This study confirmed that low levels of fluridone did not kill delta smelt. However, we found that exposure to this herbicide for only $6 \mathrm{~h}$ caused sickness in delta smelt that might weaken their ability to survive in the San Francisco Estuary (Figure 3). Exposure to fluridone for longer than $6 \mathrm{~h}$ might cause severe damage to fish organs, which may even kill fish. Longer exposure to fluridone may also affect the ability of delta smelt to reproduce, which would mean fewer delta smelt in the Estuary.

\section{Figure 3}

Potential negative impacts of fluridone on delta smelt.

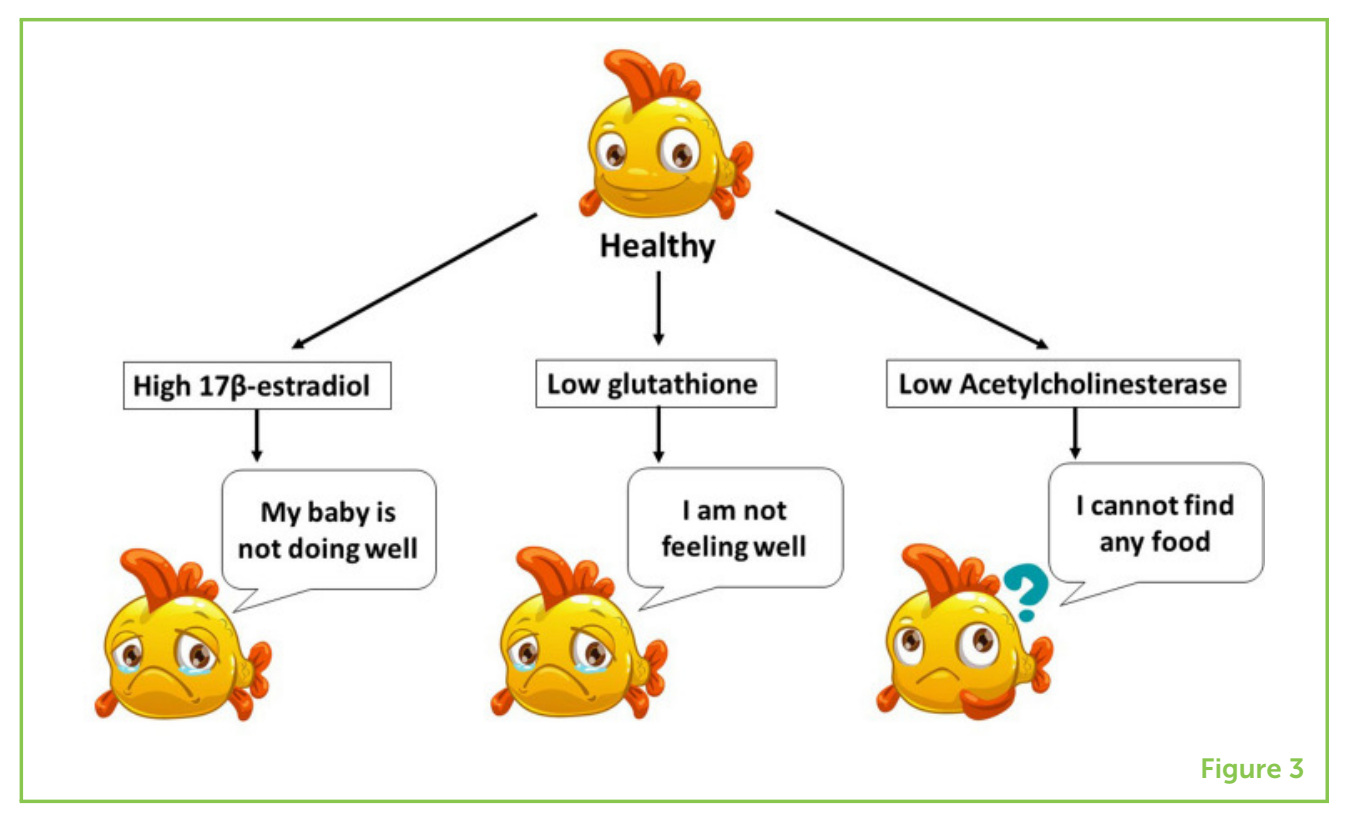


Researchers and local environmental agencies have reported that populations of other pelagic fish species, like striped bass, threadfin shad, and longfin smelt, are also declining in the San Francisco Estuary. The cause of these declines is not known, but our study suggests that herbicides like fluridone could weaken the health of other fishes in the Estuary. Unfortunately, new types of herbicides are being added to the San Francisco Estuary all the time, and we do not know how they will affect the aquatic animals.

\section{WHAT CAN WE DO?}

We all agree that chemicals like herbicides can make our lives a lot easier. However, we sometimes get a little bit careless with them. Overuse of chemicals can end up polluting the canals, rivers, or streams that we depend on as water sources. Products like herbicides and pesticides need to be used in moderation to keep our water safe. Understanding how these chemicals enter our waters is important, so farmers and other people who use herbicides can take steps to prevent this pollution from happening. Public awareness campaigns can be created to help inform the farmers about the environmental effects of overusing herbicides. By helping everyone to understand the negative effects that herbicides can have on local fish species, we will protect not only our own health but the health of the many fish in the San Francisco Estuary and other important waters.

\section{ORIGINAL SOURCE ARTICLE}

Jin, J., Kurobe, T., Ramírez-Duarte, W., Bolotaolo, M., Lam, C., Pandey, P., et al. 2018. Sub-lethal effects of herbicides penoxsulam, imazamox, fluridone and glyphosate on Delta Smelt (Hypomesus transpacificus). Aquat. Toxicol. 197:79-88. doi: 10.1016/j.aquatox.2018.01.019

\section{REFERENCES}

1. Nieves-Puigdoller, K., Björnsson, B. T., and Mccormick, S. D. 2007. Effects of hexazinone and atrazine on the physiology and endocrinology of smolt development in atlantic salmon. Aquat. Toxicol. 84:27-37. doi: 10.1016/ j.aquatox.2007.05.011

2. Salaberria, I., Hansen, B. H., Asensio, V., Olsvik, P. A., Andersen, R. A., and Jenssen, B. M. 2009. Effects of atrazine on hepatic metabolism and endocrine homeostasis in rainbow trout (Oncorhynchus mykiss). Toxicol. Appl. Pharm. 234:98-106. doi: 10.1016/j.taap.2008.09.023

SUBMITTED: 01 October 2020; ACCEPTED: 30 July 2021; PUBLISHED ONLINE: 03 September 2021. 
EDITED BY: Peggy W. Lehman, California Department of Water Resources, United States

CITATION: Huynh K, Kurobe T, Stillway M, Lam C and Teh S (2021) What Does Not Kill Can Weaken: How Herbicides Impact Fish In The San Francisco Estuary. Front. Young Minds 9:612966. doi: 10.3389/frym.2021.612966

CONFLICT OF INTEREST: The authors declare that the research was conducted in the absence of any commercial or financial relationships that could be construed as a potential conflict of interest.

COPYRIGHT @ 2021 Huynh, Kurobe, Stillway, Lam and Teh. This is an open-access article distributed under the terms of the Creative Commons Attribution License (CC BY). The use, distribution or reproduction in other forums is permitted, provided the original author(s) and the copyright owner(s) are credited and that the original publication in this journal is cited, in accordance with accepted academic practice. No use, distribution or reproduction is permitted which does not comply with these terms.

\section{YOUNG REVIEWERS}
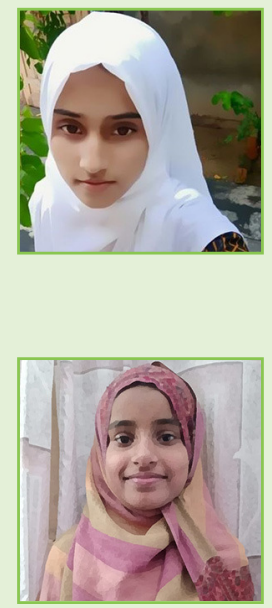

\section{SAMEEN, AGE: 15}

Hello, I am Sameen from and I have a strong interest in science subjects, but I like studying biology more. I love to explore natural processes, particularly in aquatic ecosystems. I love to read science articles in the newspaper and learn new languages. Besides, I wish to participate in environmental clubs and field trips. I want to study freshwater ecosystems and molecular biology when I grow up.

\section{ZAINAB, AGE: 12}

$\mathrm{Hi}$, My name is Zainab, and I live in a small village. I am excited about species relationships and environmental changes, perhaps why I love knowing about species and ecosystem biology. Apart from that, I want to learn about the history of species and their environment. I like to go to the countryside and see the variety of land plants and animal species. I am also willing for online learning activities related to biology and ecosystems.

\section{AUTHORS}
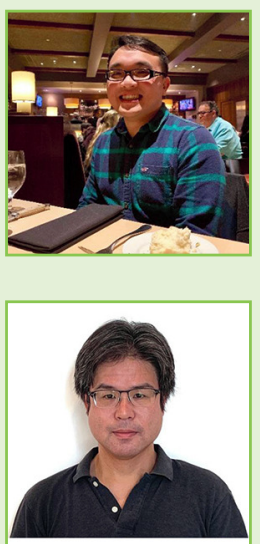

\section{KHIET HUYNH}

I am a lab assistant working in the Aquatic Health Program of the University of California, Davis. I am studying the health of delta smelt in the wild and trying to figure out what their ideal habitat is. My goal is to preserve the delta smelt and hopefully recover their population in the future. *khihuynh@ucdavis.edu

\section{TOMOFUMI KUROBE}

I am an assistant professor in aquatic toxicology at the University of California, Davis. I have been investigating various ecological issues including impacts of contaminants (e.g., pharmaceutical and personal care products, algal toxins, pesticides) on aquatic 

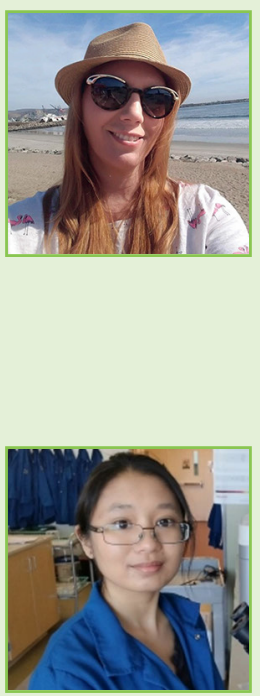

organisms such as phytoplankton, copepods, and fishes. My goal is to mitigate ecological issues using scientific knowledge. Are you interested in water quality? Please email me: tkurobe@ucdavis.edu. ${ }^{\dagger}$ orcid.org/0000-0003-3906-1989

\section{MARIE STILLWAY}

I am an environmental toxicologist at University of California, Davis. My research focus is assessing water quality and ecosystem health. I evaluate the effects and interactions of environmental stressors (e.g., pesticides, herbicides, and chemicals of emerging concern) on fishes, invertebrates, and algal species of the San Francisco Bay-Delta through toxicity testing. These experiments are conducted both in the lab and in the field. I started working here as an undergrad student and now manage the Aquatic Toxicology Laboratory.

\section{CHELSEA LAM}

I am a graduate student at University of California, Davis. My research focus is studying about phytoplankton communities. I assess the effects and interactions of pesticides and nutrient inputs from human activities on algal species of the San Francisco Bay-Delta.

\section{SWEE TEH}

Swee Teh is director of the Aquatic Health Program at the School of Veterinary Medicine, University of California, Davis. He is also director of the Aquatic Toxicology Laboratory; a state-certified laboratory engaged in monitoring and assessing ambient water quality and aquatic ecosystem health. He has published over 100 research articles. His research interests are aquatic health, including the effects of polluting chemicals on aquatic organisms and ecosystems. He has been married to his wife Foo-Ching for 39 years. They have 2 grown children who live in California. 